\title{
Children's awareness of healthy behaviors - validity of Beauty \& Health and Dietary Knowledge \& Habits scales
}

\begin{abstract}
BACKGROUND
The WHO identifies eating habits as the main factor determining body weight in both children and adults. Obesity and underweight are related to health as well as physical attractiveness. Children become aware of the role of healthy nutrition and its relationship to one's body shape in early childhood. In order to perform a direct study in children aged 5 to 9 , the Beauty \& Health (B\&H) and Dietary Knowledge \& Habits (DKH) scales were developed.
\end{abstract}

\section{PARTICIPANTS AND PROCEDURE}

The validation procedure involved 721 children assigned to two groups divided with regard to age and education: years 0 to 1 (ages 5-7) and years 2 to 3 (ages 8-9).

\section{RESULTS}

The $\mathrm{B} \& \mathrm{H}$ scale allows one to determine how children attribute social success and health-related behaviors to women and men with different body shape. The B\&H scale is composed of 18 questions. Some of them are supported with illustrations presenting various healthy behaviors. The child is asked to match each activity to one of three pictures presenting adults with different body shapes (slim, normal, and obese). The survey includes questions regarding social functioning of persons with the different body types. The questionnaire was prepared in two variants, for girls and boys, referring to women and men, respectively.

The DKH scale comprises 50 illustrations of healthy and unhealthy food products. DKH consists of two subscales. The first assesses the child's nutritional knowledge; the researcher shows various pictures of food while the child decides to which group (healthy, unhealthy) these meals belong. The second subscale allows the assessment of the child's eating habits. The child is shown the same pictures and asked how often he/she eats these meals (very often, only sometimes, very rarely or never). Using the same pictures twice allows an estimate to be made of the cohesion of the child's nutritional knowledge and their eating habits.

\section{CONCLUSIONS}

The Beauty \& Health and Dietary Knowledge \& Habits scales show good psychometric values and can be successfully used to study children aged 5-9 for both scientific purposes and to help assess the effectiveness of school health programs.

\section{KEY WORDS}

scale validation; gender stereotypes and health; nutritional knowledge; body image; elementary schoolers

ORganization - 1: Institute of Psychology, University of Gdansk, Gdansk, Poland, 2: Department of Health Psychology,

Gdansk University of Physical Education and Sport, Gdansk, Poland

aUthors' Contributions - A: Study design - B: Data collection - C: Statistical analysis - D: Data interpretation .

E: Manuscript preparation · F: Literature search · G: Funds collection

Corresponding Author - Prof. Mariusz Lipowski, Department of Health Psychology, Gdansk University of Physical

Education and Sport, 1 Kazimierza Górskiego Str., 80-336 Gdansk, Poland, e-mail: mariusz.lipowski@awfis.gda.pl

TO CITE THIS ARTICLE - Lipowska, M., \& Lipowski, M. (2018). Children's awareness of healthy behaviors - validity

of Beauty \& Health and Dietary Knowledge \& Habits scales. Health Psychology Report, 6(4), 361-374. https://doi.

org/10.5114/hpr.2018.74688

RECEIVED 18.01.2018 - REVIEWED 19.02.2018 · ACCEPTED 20.02.2018 · PUBLISHED 28.12.2018 


\section{BACKGROUND}

"A healthy mind in a healthy body" is a well-known proverb that emphasizes the relationship between physical and mental health. Concern for health is inseparable from concern for the body and its functioning, fitness, and also its appearance (Cash \& Smolak, 2011). The long-term health of a child is rooted in both genetic and environmental factors, and the dynamic interplay between them. Critically important are early childhood experiences as they can modify biological predispositions (Anzman, Rollins, \& Birch, 2010; Loprinzi \& Trost, 2010). Hence, the early development of health-related practices, such as eating habits or participating in physical activity, may play a profound prophylactic role. Parents may influence their children's eating behaviors by managing dietary restrictions, providing knowledge about nutritional values of meals, and simply demonstrating eating and health practices (Scaglioni, Arrizza, Vecchi, \& Tedeschi, 2011; Utter, Scragg, Schaaf, \& Mhurchu, 2008). Proper nutrition is one of the most crucial concerns during childhood, as maintaining healthy dieting has enduring consequences which carry on into adulthood (Anzman et al., 2010; Llewellyn, van Jaarsveld, Boniface, Carnell, \& Wardle, 2008; Nicklaus, Boggio, Chabanet, \& Issanchou, 2005; Scaglioni et al., 2011; Skinner, Carruth, Bounds, Ziegler, \& Reidy, 2002).

Since the WHO recognizes obesity as a worldwide epidemic, forming correct eating habits among young children is increasingly important. The worldwide prevalence of obesity nearly doubled between 1980 and 2008. In 2008, 35\% of adults aged 20+ were overweight (34\% men and $35 \%$ of women; WHO, 2013). In Poland, $59 \%$ of women and $69 \%$ of men are overweight, which is one of the highest percentages in EU countries (Wojtyniak \& Goryński, 2016). Children are at particular risk and the prevalence of childhood obesity is a constantly rising trend (Nishtar, Gluckman, \& Armstrong, 2016). In Poland, up to $22 \%$ of school-aged children are overweight or obese (Kułaga et al., 2011, 2016a), and for preschoolers these estimates range from 12.2 to $17.2 \%$ in boys and 15 to $19.1 \%$ in girls (Kułaga et al., 2016b). These numbers are comparable to (or even higher than) other western countries (Branca \& Nikogosian, 2007). In light of the rapidly growing number of food-related illnesses, shaping proper nutrition among children is one of the most pivotal concerns, especially since the changing of eating habits and preferences is often indicated as one of the main challenges in treating health problems among adolescents and adults (Meule, 2017; Obara-Gołębiowska, Brycz, Lipowska, \& Lipowski, 2018).

Incorrect body weight is not only a health issue but also an essential component of body image. The body shape is considered the main indicator of physi- cal attractiveness; in their assessments, women concentrate on body weight and shape (Lipowska \& Lipowski, 2015; Swami et al., 2010; Tiggemann, 2004), while men concentrate on muscles (Lipowski \& Lipowska, 2015; Ridgeway \& Tylka, 2005; Tod \& Edwards, 2013). When children judge an adult's appearance, they first use words like "fat - thin" (Harriger, Calogero, Witherington, \& Smith, 2010; Tiggemann \& Wilson-Barrett, 1998). The creation of beauty ideals takes place within the process of socialization; during their development, a child acquires numerous skills by means of observation. Parents or guardians are the first role models - it is their behaviors, attitudes, and emotional reactions that are adopted by children to a large extent. Moreover, the mother and the father are the first role models who deliver patterns of behavior that are in accord with social and gender roles, and they are also the first indicators of beauty (Lowes \& Tiggemann, 2003). Parents also express direct approval or disapproval of the appearance of the people they meet or see in the media as well as of their own children. As they grow older, children are also more and more affected by the media (Slater \& Tiggemann, 2016).

It is worth noting that both the parents' appearances and opinions of beauty ideals and their behaviors in relation to concern for the body constitute a point of reference for the child. Children involuntarily observe their parents' behaviors aimed at improving their appearance; these can be both health-related actions like paying attention to a balanced diet and physical activity, but also restrictive slimming, frequent self-weighing, or use of laxatives (Dohnt \& Tiggemann, 2005). It should be emphasized that the ways in which parents encourage their children to undertake healthy behaviors are different for girls and boys. Girls should have a balanced diet and be physically active to care for their beauty (e.g. have a shapely figure and beautiful hair), while boys should do these things in order to be strong.

Attractive appearance is also important because beauty creates a clear stereotype and people with certain physical features are viewed as having certain mental characteristics (Griffin \& Langlois, 2006). Physically attractive people are perceived as more intelligent, eloquent, cultured, balanced, independent - better socially adapted in general, they are usually attributed more self-confidence, which is of great importance when it comes to both professional and social interactions with others (Eagly, Ashmore, Makhijani, \& Longo, 1991). Beauty equals interpersonal success, beauty is the key factor in prestige and social recognition, or so advertising seems to tell us (Lemay, Clark, \& Greenberg, 2010). Appearance flaws, and especially obesity, are frequent causes of stigmatization (Asbury \& Woszidlo, 2016; Lipowska, Bidzan, Mazurkiewicz, \& Lipowski, 2015). In the opinion of their peers, obese teenagers 
are not only thought of as physically unattractive but also as unable to maintain interpersonal relations (Radoszewska, 2009; Strauss \& Pollack, 2003), and children, when describing "fat people", often refer to them as lazy or sloppy (Davison \& Birch, 2004; Puhl \& Latner, 2007).

\section{THE PRESENT STUDY}

The importance of the problem of obesity, both from the physical health and the quality of social life (at each stage of life) perspectives, resulted in studies on pro-health behaviors among children. Yet it is worth emphasizing that most of these studies were based on an assessment of children nutrition made by their parents. The meta-analysis conducted by de LauzonGuillain et al. (2012) indicated the need to further develop tools based on studying children directly and not their guardians.

What is more, despite the researchers' interest in the issues of stereotypical perception of beauty by children (Coyne, Linder, Rasmussen, Nelson, \& Birkbeck, 2016; Ramsey \& Langlois, 2002), there are no methods that allow one to determine to what extent the stereotypical way of relating physical attractiveness and social functioning is already formed in young children.

In order to perform the study on children directly, two scales - Beauty \& Health and Dietary Knowledge \& Habits - were developed, engaging children aged 5-9 in the form of play.

\section{PARTICIPANTS AND PROCEDURE}

A total of 721 children took part in the study. Children were assigned to one of four groups based on age and sex (see Table 1).

\section{PROCEDURE}

The study was conducted in the Pomorskie Region, where random selection of both the cities - based on their size - and then of educational institutions was made. Eventually, $20 \%$ of the educational institutions (nursery schools and primary schools) that run compulsory pre-school education units (the so-called "zeroth grade") were selected and invited to participate in the study. A positive response was obtained from 58 school principals. In nursery schools, only children attending the eldest group following the compulsory preschool curriculum, while in primary schools year "0" to 3 pupils (the so-called integrated education). Before commencing the study, the parents of all children had been presented the study procedure and informed about the possibility to withdraw partici-
Table 1

Characteristics of study participants - sex and year of education

\begin{tabular}{lccc}
\hline Grade & Girls & Boys & Total \\
\hline Zero and first & 209 & 179 & 388 \\
grade & $(28.99 \%)$ & $(24.83 \%)$ & $(53.81 \%)$ \\
Second and & 143 & 190 & 333 \\
third grade & $(19.83 \%)$ & $(26.35 \%)$ & $(46.19 \%)$ \\
& 352 & 369 & 721 \\
Total & $(48.82 \%)$ & $(51.18 \%)$ & $(100.00 \%)$ \\
\hline
\end{tabular}

Validity of Beauty $\&$ Health and Dietary Knowledge \& Habits scales

pation at any stage of the project. The parents of all children included in the study had signed a written consent for participation in the study.

The study was conducted individually at the premises of the nursery school or school the children attended. The study was conducted after breakfast in order to avoid the influence of hunger on answers to question about eating habits and knowledge about nutritional values of food products. It was conducted in two rounds, in which children were surveyed with both Beauty \& Health and Dietary Knowledge \& Habits. During the first meeting, the first two subscales of B\&H and DKH were used, and the next two after at least two weeks - in order to avoid memorizing the answers from the firstround questions.

The protocol of this study was approved by the Ethics Board for Research Projects at the Institute of Psychology, University of Gdansk, Poland (decision no. $17 / 2013)$.

\section{MEASURES}

\section{BEAUTY \& HEALTH ${ }^{1}$}

The scale allows the identification of how children attribute social success and health-related behavior to women and men with different body shapes. It is designed to study children aged 5-9. The Beauty \& Health scale study procedure consists of children matching features related to pro-health or antihealth behaviors and social status to female and male silhouettes with distinctly different body weights.

\section{Components}

The method consists of a set of illustrations, two charts with silhouettes of bodies, and two answer sheets.

Illustrations are $118 \times 8 \mathrm{~cm}$ drawings that depict the individual questions; they present various health-promoting and health-threatening behaviors (e.g. running or lazing around) as well as indicators 


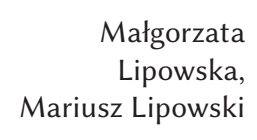

A

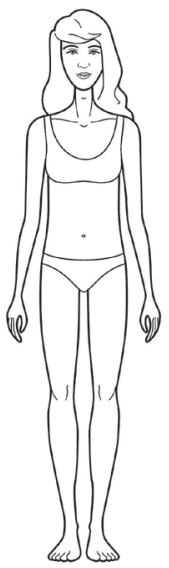

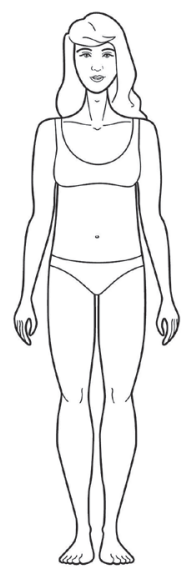

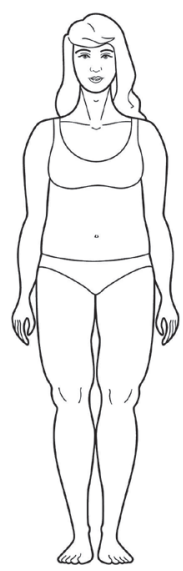

B

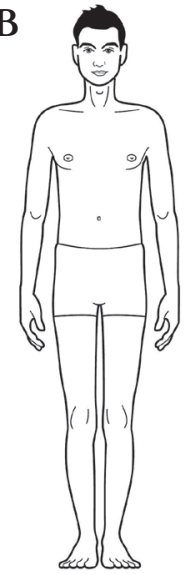

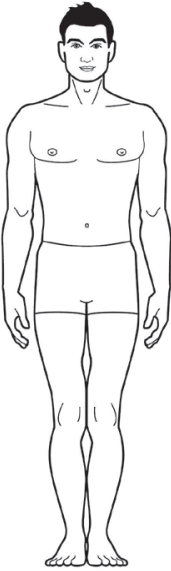

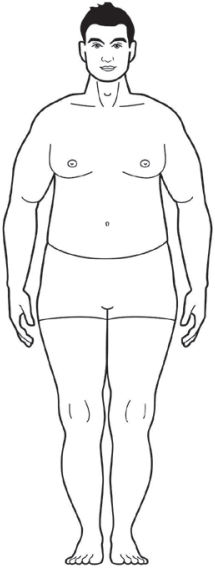

Figure 1. Female and male silhouettes used in B\&H.

of social success (e.g. having many friends). All the illustrations are computer-made in a way that prevents them from being identified with a gender. Each illustration is marked with a number facing the researcher, so that he can attribute it to the question.

Charts with body silhouettes are white cardboard sheets (A4) with three silhouettes in underwear printed on them. One chart shows three female silhouettes (slim, normal, and obese), the other three male silhouettes (slim, normal, and obese). The details of the silhouettes are minimized (Figure 1).

Answer sheets are prepared in two versions: one to attributed features to women, the other to men. They include instructions on how to conduct the survey and the text to be dictated to the child. There are 18 questions below the instructions as well as a scale to indicate an answer from 1 to 3 (where: 1 is a slim person, 2 = normal weight, 3 = obese person).

\section{Conducting the survey}

The survey can be conducted using the B\&H woman subscale and the $\mathrm{B} \& \mathrm{H}$ man subscale independently or jointly. If the researcher decides to use both scales in the study, a break of at least two weeks between the use of the first and the second scale must be made. The break period between the two parts of the study is intended to minimize the possibility of the child being influenced by previous answers. The scales may be used in any order, but the conditions of conducting the survey should be as similar as possible.

\section{$B \& H$ woman subscale}

The researcher places the chart with the three silhouettes of the same woman in front of the child and asks: "Which woman is the prettiest?" The chart remains in front of the child until the end of the survey. After marking the answer, he says: "I have a task for you - I am going to ask you different questions and show you pictures. I want you to choose the woman who you think fits best to what is drawn. Let's start!" Next, the researcher shows an illustration to the child and asks (in accordance with the questions on the answer sheet) to indicate a silhouette: "Show me, which woman...?” For the next questions (13-17) no drawings are presented. Only girls are asked the last question: "Show me, which woman would you like to look like when you grow up?"

\section{B\&H man subscale}

The researcher places the chart with three silhouettes of the same man in front of the child and asks: "Which man is the most handsome?" The chart remains in front of the child until the end of the survey. After marking the answer, he says: "I have a task for you - I am going to ask you different questions and show you pictures. I want you to choose the man who you think fits best to what is drawn. Let's start!" Next, the researcher shows a picture to the child and asks (in accordance with the questions on the answer sheet) to indicate a silhouette: "Show me, which man...?" For the next questions (13-17) no drawings are presented. Only boys are asked the last question: "Show me, which man would you like to look like when you grow up?"

\section{Calculating the results}

After conducting the survey, points are attributed to each silhouette (female and male separately) on three scales: social success, pro-health behaviors, and antihealth behaviors. Each silhouette can get a maximum of six points for social success, seven for pro-health behaviors, and three for anti-health behaviors. The distribution of the results allows one to determine to which female and male silhouettes girls and boys most attribute certain features. 


\section{Scale validation}

In the first step, differences were compared in the children's attribution of traits related to the success and health behaviors of women and men of different silhouettes. For this purpose, multiple paired samples test statistics were used. As can be seen in Table 2, the examined children most often associated traits related to the success of women and men with normal body structure, and least often with people with obese body shape. Children most often attributed pro-health behaviors to slim women and slim men, and again and least often to people with obese body shape. In the case of anti-health behaviors, significant differences were noted only between obese and slim and obese and normal silhouettes - children did not notice differences in the attribution of anti-health behaviors in the case of people with slim and normal body shape.

While conducting the study, it caught researchers' attention that 'running' was relatively often associated with a silhouette of an obese woman. Researchers wrote down all the children's comments and a comment that "fat people have to run to lose weight' was recorded several times.

In the next step, it was verified whether the perception of success and health behaviors of people with different body shapes is different for women and men. For this purpose, paired samples test statistics were used. As can be seen in Table 3, significant differences were noted in the children's attribution of success to women and men who have a slim build:
Validity of Beauty \& Health and Dietary Knowledge \& Habits scales

\section{Table 2}

Paired samples test statistics for average percentages of traits associated with success and health behaviors attributed by children to three women's and three men's silhouettes

\begin{tabular}{|c|c|c|c|c|c|c|c|c|c|}
\hline \multirow[t]{2}{*}{ Variable } & \multicolumn{2}{|c|}{$\operatorname{Slim}(\mathrm{A})$} & \multicolumn{2}{|c|}{ Normal (B) } & \multicolumn{2}{|c|}{ Obese $(\mathrm{C})$} & \multirow{2}{*}{$\begin{array}{c}t \\
(\mathrm{~A}-\mathrm{B})\end{array}$} & \multirow{2}{*}{$\begin{array}{c}t \\
(\mathrm{~A}-\mathrm{C})\end{array}$} & \multirow{2}{*}{$\begin{array}{c}t \\
(\mathrm{~B}-\mathrm{C})\end{array}$} \\
\hline & $M$ & $S D$ & $M$ & $S D$ & $M$ & $S D$ & & & \\
\hline Woman's success & 0.37 & 0.27 & 0.49 & 0.29 & 0.13 & 0.17 & $-6.20^{* *}$ & $18.51^{* *}$ & $25.44^{* *}$ \\
\hline Man's success & 0.33 & 0.28 & 0.53 & 0.30 & 0.13 & 0.18 & $-10.08^{* *}$ & $14.44^{* *}$ & $26.49^{* *}$ \\
\hline $\begin{array}{l}\text { Woman's pro-health } \\
\text { behaviors }\end{array}$ & 0.54 & 0.28 & 0.33 & 0.24 & 0.12 & 0.16 & $11.26^{* *}$ & $28.73^{* *}$ & $18.79^{* *}$ \\
\hline $\begin{array}{l}\text { Man's pro-health } \\
\text { behaviors }\end{array}$ & 0.50 & 0.28 & 0.38 & 0.25 & 0.11 & 0.17 & $6.58^{* *}$ & $27.37^{* *}$ & $21.92^{* *}$ \\
\hline $\begin{array}{l}\text { Woman's anti-health } \\
\text { behaviors }\end{array}$ & 0.14 & 0.23 & 0.16 & 0.26 & 0.70 & 0.34 & -1.77 & $-28.84^{* *}$ & $-26.04^{* *}$ \\
\hline $\begin{array}{l}\text { Man's anti-health } \\
\text { behaviors }\end{array}$ & 0.13 & 0.23 & 0.15 & 0.26 & 0.71 & 0.35 & -1.49 & $-29.07^{* *}$ & $-26.32^{* *}$ \\
\hline
\end{tabular}

Table 3

Paired samples test statistics for average percentages of traits associated with success and health behaviors attributed by children to people with different body shapes - comparison of the perception of women and men

\begin{tabular}{|c|c|c|c|c|c|}
\hline \multirow[t]{2}{*}{ Variable } & \multicolumn{2}{|c|}{ Woman } & \multicolumn{2}{|c|}{ Man } & \multirow[t]{2}{*}{$t$} \\
\hline & M & $S D$ & M & $S D$ & \\
\hline Success of a slim silhouette & 0.37 & 0.27 & 0.33 & 0.28 & $4.36^{* *}$ \\
\hline Success of a normal silhouette & 0.49 & 0.29 & 0.53 & 0.30 & $-3.63^{* *}$ \\
\hline Success of an obese silhouette & 0.13 & 0.17 & 0.13 & 0.18 & -0.58 \\
\hline Pro-health behaviors of a slim silhouette & 0.54 & 0.28 & 0.50 & 0.28 & 3.78 * * \\
\hline Pro-health behaviors of a normal silhouette & 0.33 & 0.24 & 0.38 & 0.25 & $-4.99^{* *}$ \\
\hline Pro-health behaviors of an obese silhouette & 0.12 & 0.16 & 0.11 & 0.17 & 2.00 \\
\hline Anti-health behaviors of a slim silhouette & 0.14 & 0.23 & 0.13 & 0.23 & 0.34 \\
\hline Anti-health behaviors of a normal silhouette & 0.16 & 0.26 & 0.15 & 0.26 & 0.71 \\
\hline Anti-health behaviors of an obese silhouette & 0.70 & 0.34 & 0.71 & 0.35 & -0.99 \\
\hline
\end{tabular}

Note. ${ }^{* *} p<.01$ 
children more often attributed success to a slim woman than to a slim man. The opposite result was observed in the case of women and men who have a normal body structure. The same pattern of differences was noted in the case of pro-health behavior. Analyses did not reveal any significant differences for anti-health behaviors.

In the next step, the differences between girls and boys in the perception of women's and men's silhouettes were compared. For this purpose, the t test for independent samples was used. As can be seen in Table 4, significant differences were noted only in attributing success to a slim woman (boys more often than girls attributed to the slim woman the traits associated with success) and a normal woman (girls more often than boys attributed to the normal woman the traits associated with success), as well as the pro-health behaviors of a slim woman (girls more often than boys attributed to the normal woman the pro-health behaviors) and anti-behaviors of a normal man (girls more often than boys attributed to the normal man the anti-health behaviors).

We also compared the perception of women's and men's body types among children at various stages of education ('zero and first grade' versus 'second and third grade'). It can be seen in Table 5 that older children were more critical in assessing the possibility of achieving success by both obese women and men. Both younger and older children were more likely to associate pro-health behaviors with silhouettes of men and women when these silhouettes were slimmer. The opposite pattern was observed for anti-health behaviors. It is also visible that older children more decidedly attributed pro- and anti-health behaviors depending on obesity levels in the case of both men and women (they were more critical).

\section{DIETARY KNOWLEDGE \& HABITS ${ }^{2}$}

This scale measures levels of knowledge (Dietary Knowledge subscale) and types of eating habits (Dietary Habits subscale) of children aged 5-9. This original instrument comprises 50 illustrations of various food products classified as healthy or unhealthy.

In the first, pilot version of the Dietary Knowledge \& Habits (DKH) scale, it consisted of 60 pictures of meals which children should be familiar with.

Table 4

Differences between girls and boys for average percentages of traits associated with social success and health behaviors attributed to people with different body shapes

\begin{tabular}{|c|c|c|c|c|c|c|}
\hline \multirow[t]{2}{*}{ Attributed traits } & \multirow[t]{2}{*}{ Silhouette } & \multicolumn{2}{|c|}{ Girls $(n=353)$} & \multicolumn{2}{|c|}{ Boys $(n=367)$} & \multirow[t]{2}{*}{$t$} \\
\hline & & $M$ & $S D$ & $M$ & $S D$ & \\
\hline \multirow[t]{6}{*}{ Social success } & Slim woman & 0.35 & 0.27 & 0.39 & 0.28 & $-2.12^{*}$ \\
\hline & Normal woman & 0.52 & 0.28 & 0.47 & 0.29 & $2.02^{*}$ \\
\hline & Obese woman & 0.13 & 0.16 & 0.13 & 0.18 & -0.04 \\
\hline & Slim man & 0.32 & 0.28 & 0.33 & 0.28 & -0.23 \\
\hline & Normal man & 0.54 & 0.30 & 0.53 & 0.30 & 0.25 \\
\hline & Obese man & 0.13 & 0.18 & 0.13 & 0.18 & -0.08 \\
\hline \multirow{6}{*}{$\begin{array}{l}\text { Pro-health } \\
\text { behaviors }\end{array}$} & Slim woman & 0.52 & 0.27 & 0.55 & 0.28 & -1.44 \\
\hline & Normal woman & 0.35 & 0.24 & 0.31 & 0.23 & $2.24^{*}$ \\
\hline & Obese woman & 0.12 & 0.16 & 0.12 & 0.17 & -0.78 \\
\hline & Slim man & 0.48 & 0.28 & 0.52 & 0.27 & -1.94 \\
\hline & Normal man & 0.40 & 0.26 & 0.36 & 0.25 & 1.82 \\
\hline & Obese man & 0.11 & 0.17 & 0.11 & 0.17 & 0.41 \\
\hline \multirow{6}{*}{$\begin{array}{l}\text { Anti-health } \\
\text { behaviors }\end{array}$} & Slim woman & 0.14 & 0.23 & 0.14 & 0.24 & -0.02 \\
\hline & Normal woman & 0.17 & 0.26 & 0.15 & 0.25 & 1.52 \\
\hline & Obese woman & 0.69 & 0.35 & 0.71 & 0.34 & -1.16 \\
\hline & Slim man & 0.13 & 0.22 & 0.14 & 0.25 & -0.40 \\
\hline & Normal man & 0.18 & 0.28 & 0.13 & 0.24 & $2.46^{* *}$ \\
\hline & Obese man & 0.69 & 0.35 & 0.73 & 0.35 & -1.58 \\
\hline
\end{tabular}

Note. ${ }^{*} p<.05,{ }^{* *} p<.01$ 
Table 5

Children's grade differences for average percentages of traits associated with social success and health behaviors attributed to people with different body shapes

\begin{tabular}{|c|c|c|c|c|c|c|}
\hline \multirow[t]{2}{*}{ Attributed traits } & \multirow[t]{2}{*}{ Silhouette } & \multicolumn{2}{|c|}{$\begin{array}{l}\text { Zero and first grade } \\
\qquad(n=387)\end{array}$} & \multicolumn{2}{|c|}{$\begin{array}{l}\text { Second and third grade } \\
\qquad(n=333)\end{array}$} & \multirow[t]{2}{*}{$t$} \\
\hline & & $M$ & $S D$ & $M$ & $S D$ & \\
\hline \multirow[t]{6}{*}{ Social success } & Slim woman & 0.33 & 0.23 & 0.42 & 0.31 & $-4.64^{* *}$ \\
\hline & Normal woman & 0.49 & 0.27 & 0.50 & 0.31 & -0.76 \\
\hline & Obese woman & 0.18 & 0.18 & 0.07 & 0.13 & $8.99 * *$ \\
\hline & Slim man & 0.31 & 0.25 & 0.35 & 0.31 & -1.97 \\
\hline & Normal man & 0.49 & 0.27 & 0.58 & 0.32 & $-4.04^{* *}$ \\
\hline & Obese man & 0.19 & 0.20 & 0.06 & 0.12 & $10.21^{* *}$ \\
\hline \multirow{6}{*}{$\begin{array}{l}\text { Pro-health } \\
\text { behaviors }\end{array}$} & Slim woman & 0.44 & 0.24 & 0.65 & 0.28 & $-10.43^{* *}$ \\
\hline & Normal woman & 0.37 & 0.22 & 0.28 & 0.24 & $5.11^{* *}$ \\
\hline & Obese woman & 0.17 & 0.17 & 0.06 & 0.14 & $9.34^{* *}$ \\
\hline & Slim man & 0.42 & 0.24 & 0.59 & 0.29 & $-8.61^{* *}$ \\
\hline & Normal man & 0.41 & 0.24 & 0.35 & 0.27 & $3.17^{* *}$ \\
\hline & Obese man & 0.16 & 0.18 & 0.05 & 0.13 & 9.00 ** \\
\hline \multirow{6}{*}{$\begin{array}{l}\text { Anti-health } \\
\text { behaviors }\end{array}$} & Slim woman & 0.19 & 0.24 & 0.08 & 0.21 & $6.39 * *$ \\
\hline & Normal woman & 0.25 & 0.30 & 0.05 & 0.13 & $11.31^{* *}$ \\
\hline & Obese woman & 0.55 & 0.34 & 0.87 & 0.25 & $-13.80^{* *}$ \\
\hline & Slim man & 0.21 & 0.26 & 0.04 & 0.15 & $10.05^{\text {* * }}$ \\
\hline & Normal man & 0.24 & 0.30 & 0.05 & 0.14 & $9.98^{* *}$ \\
\hline & Obese man & 0.55 & 0.36 & 0.90 & 0.22 & $-15.38^{* *}$ \\
\hline
\end{tabular}

Note. ${ }^{* *} p<.01$

Competent judges (three dieticians and a pediatrician) classified each meal into one of two groups: healthy or unhealthy. A pilot study done on a group of 230 6-year-old children led to the decision to remove 10 meals (after consulting a dietician) because children's answers were very difficult to qualify e.g. kefir is very unhealthy, because it contains live bacterial cultures which are contagious. The final version of the test contains 30 meals classified as healthy and 20 meals classified as unhealthy.

\section{Components}

The method consists of a set of pictures, two (independent) answer sheets for the researcher, and three paper plates.

The pictures are 50 captioned photos of meals, 8 by $8 \mathrm{~cm}$ in size. Meals are presented in a uniform way all meals were photographed on identical white porcelain plates. All brand names were removed from packaging and containers of foods such as yoghurt or ketchup. Each photograph is captioned in a way such that the researcher, but not the child, can read the caption. The child sees the text upside down, so that they are not influenced by the caption. The captions serve to avoid any confusion, such as whether a hot dog or a sandwich is presented in the picture.

Paper plates cut out of cardboard, white circles with print, serve for placing the pictures described in the previous paragraph. There are 'emoji' pictograms in the middle and on the rim of every plate in three colors - a green smiling face J, a grey neutral face $\mathrm{K}$, and a red sad face $\mathrm{L}$. The external diameter of the plate is $18 \mathrm{~cm}$ and the place for putting the pictures has a $12 \mathrm{~cm}$ diameter. This size allows the child to freely place the pictures (in accordance with the instructions) and to not cover the 'emojis' on the rims.

There are independent answer sheets for the $\mathrm{Di}$ etary Knowledge and the Dietary Habits subscales. They contain the instructions on how to conduct the assessment and the text to dictate to the child. Below the instructions, there are 50 answers in the form of a selection of three 'emojis'.
Validity of Beauty \& Health and Dietary Knowledge \& Habits scales 


\section{Conducting the assessment}

Assessment can be made using the Dietary Knowledge and Dietary Habits subscales independently, or by combining them. If the assessor decides to use both scales, it is necessary to have at least a twoweek time interval between using the first and the second scale. The interval is meant to minimize the possibility that the child is influenced by their previous answers. The scales can be used in any order, but it is important to make sure that the assessment conditions are as similar as possible.

Lipowska,

Mariusz Lipowski

\section{Dietary knowledge subscale}

The researcher places three plates of different colors with different emojis in front of the child and reads the instructions (pointing at the respective plates): "I have a task for you - I will show you various pictures of food. Please place on the J plate the pictures of meals which are healthy and put pictures of the unhealthy meals on the $\mathrm{L}$ plate. If you don't know whether a meal is healthy or unhealthy, you can place the picture on the K plate. Let's begin?' Then the researcher presents the child with the pictures one by one. The researcher can remind the child about the possibility to place a picture on the right plate. After each child's answer the researcher puts an $\mathrm{X}$ on the emoji selected by the child on the answer sheet.

\section{Dietary habits subscale}

The researcher places three plates of different colors with different emojis in front of the child and reads the instructions (pointing at the respective plates): "I have a task for you - I will show you various pictures of food. Please place on the J plate the pictures of meals which you eat very often, put pictures of the meals you eat only sometimes on the $\mathrm{K}$ plate, and pictures of meals which you eat very rarely or never on the L plate. Let's begin?' Then the researcher presents the child with the pictures one by one. The researcher can remind the child about the possibility to place a picture on the right plate. After each answer the researcher puts an X on the emoji selected by the child on the answer sheet.

\section{Scoring}

Using the same pictures twice allows an estimate to be made of the cohesion of the child's nutritional knowledge and their eating habits. Furthermore, this picture-based game includes elements of the thematic interview carried out with the child. The following scores are calculated based on the responses given: (a) knowledge about healthy products, (b) knowledge about unhealthy products, (c) nutrition knowledge total score, (d) healthy eat- ing habits, (e) unhealthy eating habits, (f) eating habits total score. The number of points given in the knowledge about healthy products $(\mathrm{min}=-30$, $\max =30$ points) and knowledge about unhealthy products $(\min =-20, \max =20$ points) categories are sums of correct answers minus incorrect answers. The nutrition knowledge total score is the sum of the two previous scales, i.e. correct knowledge regarding both healthy and unhealthy products $(\min =-50, \max =50$ points). The healthy eating habits subscale is the sum of correct nutritional behaviors $(\min =0, \max =30$ points), and the unhealthy eating habits subscale is the sum of incorrect nutritional behaviors $(\mathrm{min}=0$, $\max =20$ points) - on both scales, the number of points corresponds to the number of products that the child eats frequently or sometimes. The eating habits total score scale is the difference between points on: healthy eating habits minus unhealthy eating habits $(\min =-20, \max =30$ points).

\section{Scale validation}

\section{Item analysis}

Figures 2 and 3 show the frequency of correct and incorrect answers, as well as the answers "I do not know" in the examined group of children. Children usually had no difficulty in identifying healthy products (see Figure 2). The average result for all healthy products is $72 \%$ correct answers. A more significant challenge for the children involved in the study was the evaluation of unhealthy foods (see Figure 3). The most difficulties for children were: jam, mayonnaise, sausages and potato pancakes. The average result for all unhealthy products is $55 \%$ correct answers.

Table 6 shows the means and standard deviations for eating habits for each of the 50 products included in the test. In the case of binary items, the item mean is known as item difficulty, as it corresponds to the proportion of examinees who endorsed an item, so that the higher the item mean, the lower the item difficulty. Low item difficulty for healthy products means a high frequency of children eating these products. Low item difficulty for unhealthy products means that children eat little of this product. The results indicate that children often drink tea and eat potatoes, vegetables, and fresh fruits. They rarely eat beans, goulash, and dried fruits.

The reliability of the DKH test was estimated according to the internal consistency reliability method, using the $\alpha$-coefficient. In the case of binary items (eating habits part), the raw $\alpha$-coefficient reduces to the Kuder-Richardson 20 (KR20) coefficient. Conventionally, a test is considered reliable when $\alpha$ (KR20) is greater than 0.70 (Bartolucci, Bacci, \& Gnaldi, 2016). For reliability results for DKH scores see Table 7. 


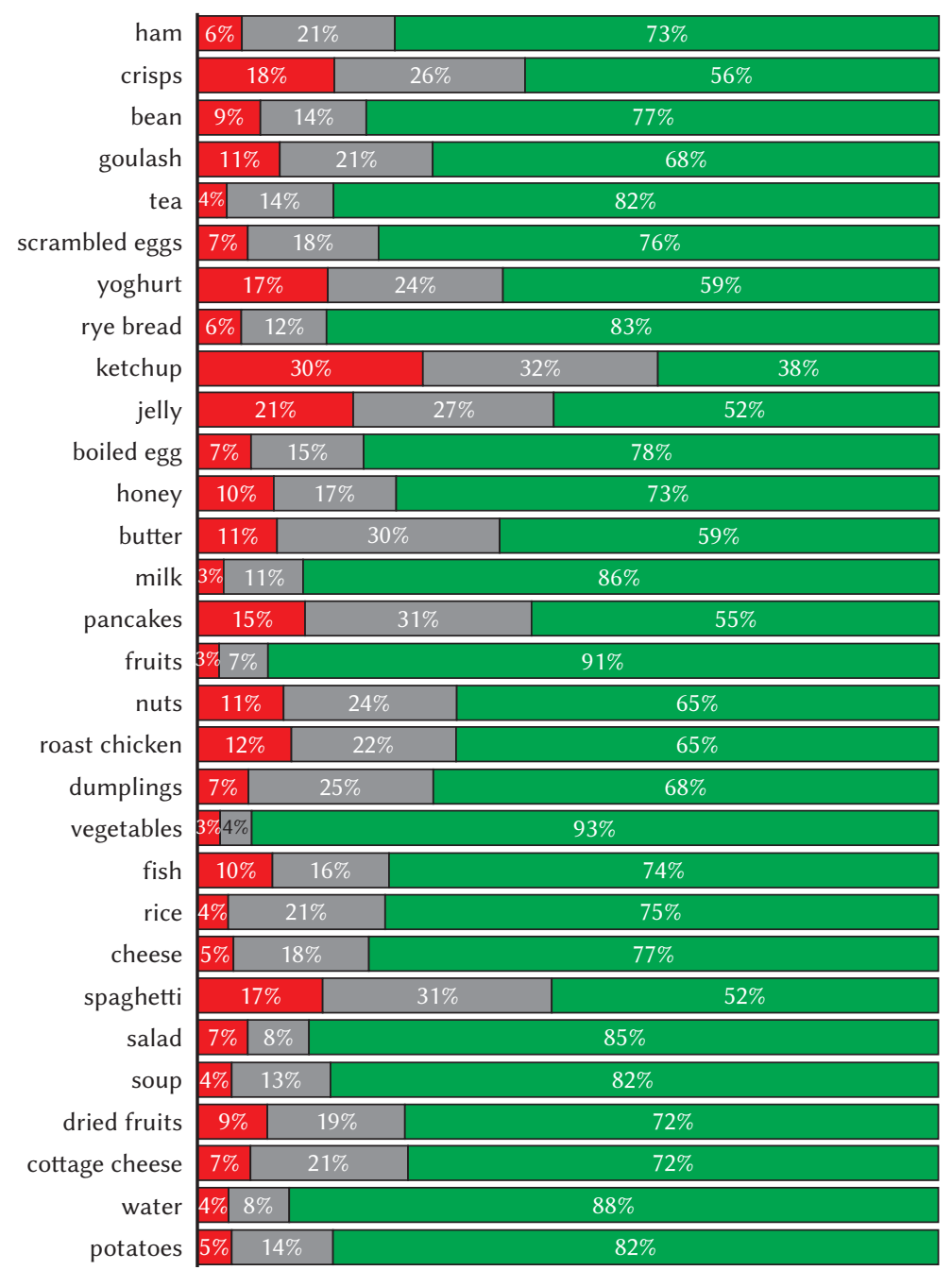

Validity of Beauty $\&$ Health and Dietary Knowledge $\&$ Habits scales

Figure 2. Answers frequency for nutrition knowledge items about healthy products $(N=721)$.

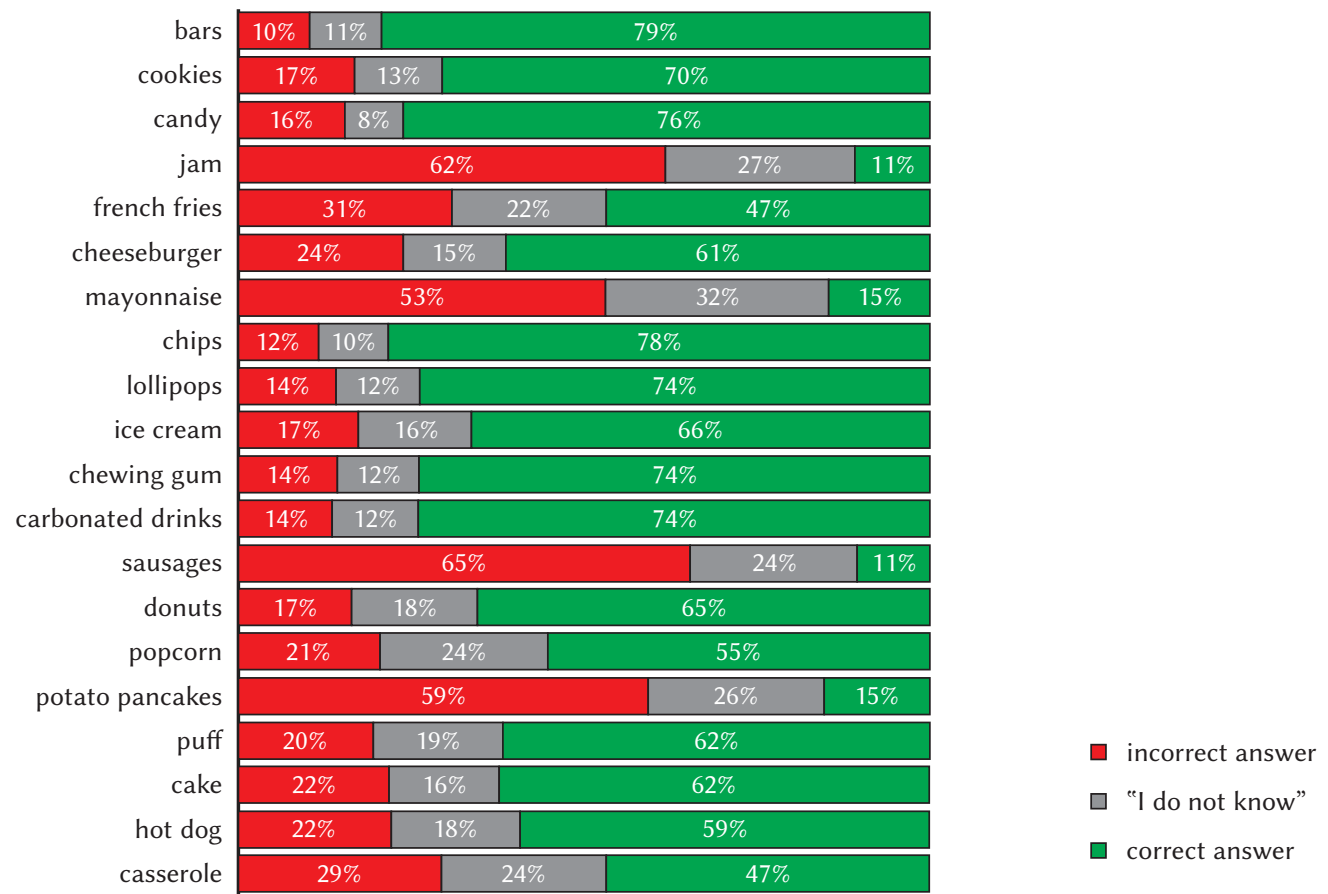

Figure 3. Answers frequency for nutrition knowledge items about unhealthy products $(N=721)$. 
Table 6

Descriptive statistics for healthy and unhealthy eating habits items

\begin{tabular}{|c|c|c|c|c|c|}
\hline \multicolumn{3}{|c|}{ Healthy eating habit } & \multicolumn{3}{|c|}{ Unhealthy eating habit } \\
\hline Item & $M$ & $S D$ & Item & $M$ & $S D$ \\
\hline Ham & 0.84 & 0.37 & Bars & 0.67 & 0.47 \\
\hline Crisps & 0.85 & 0.36 & Cookies & 0.73 & 0.44 \\
\hline Beans & 0.68 & 0.47 & Candy & 0.72 & 0.45 \\
\hline Goulash & 0.68 & 0.47 & Jam & 0.78 & 0.41 \\
\hline Tea & 0.93 & 0.26 & French fries & 0.79 & 0.41 \\
\hline Scrambled eggs & 0.81 & 0.39 & Cheeseburger & 0.53 & 0.50 \\
\hline Yoghurt & 0.86 & 0.35 & Mayonnaise & 0.61 & 0.49 \\
\hline Rye bread & 0.76 & 0.43 & Chips & 0.67 & 0.47 \\
\hline Ketchup & 0.79 & 0.41 & Lollipops & 0.71 & 0.46 \\
\hline Jelly & 0.78 & 0.42 & Ice cream & 0.80 & 0.40 \\
\hline Boiled egg & 0.78 & 0.41 & Chewing gum & 0.72 & 0.45 \\
\hline Honey & 0.73 & 0.44 & Carbonated drinks & 0.60 & 0.49 \\
\hline Butter & 0.87 & 0.34 & Sausages & 0.88 & 0.32 \\
\hline Milk & 0.89 & 0.31 & Donuts & 0.68 & 0.47 \\
\hline Pancakes & 0.88 & 0.33 & Popcorn & 0.74 & 0.44 \\
\hline Fruits & 0.95 & 0.22 & Potato pancakes & 0.78 & 0.42 \\
\hline Nuts & 0.74 & 0.44 & Puff & 0.50 & 0.50 \\
\hline Roast chicken & 0.83 & 0.38 & Cake & 0.72 & 0.45 \\
\hline Dumplings & 0.85 & 0.36 & Hot dog & 0.59 & 0.49 \\
\hline Vegetables & 0.93 & 0.25 & Casserole & 0.64 & 0.48 \\
\hline Fish & 0.71 & 0.45 & & & \\
\hline Rice & 0.84 & 0.37 & & & \\
\hline Cheese & 0.81 & 0.40 & & & \\
\hline Spaghetti & 0.83 & 0.38 & & & \\
\hline Salad & 0.80 & 0.40 & & & \\
\hline Soup & 0.88 & 0.33 & & & \\
\hline Dried fruits & 0.69 & 0.46 & & & \\
\hline Cottage cheese & 0.70 & 0.46 & & & \\
\hline Water & 0.94 & 0.23 & & & \\
\hline Potatoes & 0.91 & 0.29 & & & \\
\hline
\end{tabular}

Note. $N=721$

Table 7

Reliability statistics for DKH scores

\begin{tabular}{lcc}
\hline Scale & N of items & Standardized $\alpha /$ KR20 \\
\hline Knowledge about healthy products & 30 & 0.81 \\
Knowledge about unhealthy products & 20 & 0.90 \\
Total score - nutrition knowledge & 50 & 0.84 \\
Healthy eating habits & 30 & 0.78 \\
Unhealthy eating habits & 20 & 0.85 \\
Total score - eating habits & 50 & 0.83 \\
\hline
\end{tabular}


Table 8

Descriptive statistics and differences between gender and school grade for mean DKH scores

\begin{tabular}{|c|c|c|c|c|c|c|c|c|c|c|c|c|}
\hline \multirow[t]{2}{*}{ Scale } & \multicolumn{2}{|c|}{ Total } & \multicolumn{2}{|c|}{$\begin{array}{l}\text { Female } \\
(n=352)\end{array}$} & \multicolumn{2}{|c|}{$\begin{array}{c}\text { Male } \\
(n=369)\end{array}$} & \multirow[t]{2}{*}{$\begin{array}{c}t \\
(d f=719)\end{array}$} & \multicolumn{2}{|c|}{$\begin{array}{c}\text { Zero and } \\
\text { first grade } \\
(n=388)\end{array}$} & \multicolumn{2}{|c|}{$\begin{array}{l}\text { Second and } \\
\text { third grade } \\
\qquad(n=333)\end{array}$} & \multirow[t]{2}{*}{$\begin{array}{c}t \\
(d f=719)\end{array}$} \\
\hline & $M$ & $S D$ & $M$ & $S D$ & $M$ & $S D$ & & $M$ & $S D$ & $M$ & $S D$ & \\
\hline $\begin{array}{l}\text { Knowledge } \\
\text { about healthy } \\
\text { products }\end{array}$ & 18.73 & 7.34 & 18.45 & 7.56 & 18.99 & 7.12 & -1.00 & 18.47 & 8.07 & 19.03 & 6.38 & -1.02 \\
\hline $\begin{array}{l}\text { Knowledge } \\
\text { about } \\
\text { unhealthy } \\
\text { products }\end{array}$ & 5.63 & 8.98 & 4.82 & 9.47 & 6.39 & 8.42 & $-2.36^{*}$ & 1.78 & 9.15 & 10.11 & 6.31 & $-13.99^{* *}$ \\
\hline $\begin{array}{l}\text { Correct } \\
\text { knowledge }\end{array}$ & 32.57 & 8.05 & 31.74 & 8.46 & 33.35 & 7.56 & $-2.67^{* *}$ & 31.05 & 9.18 & 34.33 & 6.04 & $-5.57^{* *}$ \\
\hline $\begin{array}{l}\text { Incorrect } \\
\text { knowledge }\end{array}$ & 8.21 & 5.31 & 8.47 & 5.37 & 7.96 & 5.24 & 1.28 & 10.80 & 5.14 & 5.20 & 3.65 & $16.33^{* *}$ \\
\hline $\begin{array}{l}\text { Lack of } \\
\text { knowledge }\end{array}$ & 9.22 & 7.49 & 9.79 & 7.58 & 8.68 & 7.37 & $1.98^{*}$ & 8.15 & 8.09 & 10.47 & 6.51 & $-4.21^{* *}$ \\
\hline $\begin{array}{l}\text { Knowledge } \\
\text { about nutri- } \\
\text { tion - general } \\
\text { score }\end{array}$ & 24.35 & 11.39 & 23.27 & 11.97 & 25.39 & 10.72 & $-2.50^{*}$ & 20.25 & 12.48 & 29.14 & 7.56 & $-11.23^{* *}$ \\
\hline $\begin{array}{l}\text { Healthy } \\
\text { eating habits }\end{array}$ & 24.53 & 4.18 & 24.92 & 3.87 & 24.15 & 4.44 & $2.48^{*}$ & 24.49 & 4.13 & 24.56 & 4.25 & -0.23 \\
\hline $\begin{array}{l}\text { Unhealthy } \\
\text { eating habits }\end{array}$ & 13.86 & 4.61 & 13.98 & 4.54 & 13.75 & 4.68 & 0.68 & 13.91 & 4.57 & 13.79 & 4.67 & 0.35 \\
\hline $\begin{array}{l}\text { Proper eating } \\
\text { habits - } \\
\text { general score }\end{array}$ & 10.67 & 5.75 & 10.94 & 5.46 & 10.40 & 6.01 & 1.26 & 10.58 & 5.76 & 10.77 & 5.75 & -0.45 \\
\hline
\end{tabular}

Validity of Beauty \& Health and Dietary Knowledge \& Habits scales
Table 8 shows the descriptive statistics and differences between gender and school grade for mean DKH scores. The results indicate that boys have greater knowledge about unhealthy products compared to girls, and less often also "do not know" about particular products. Furthermore, older children obtained significantly higher scores on all measured aspects of knowledge. However, there were neither differences between girls and boys nor differences between pupils of different grades in terms of eating habits. The only exception is healthy eating habits, in which girls obtained higher scores than boys.

Table 9 contains norms (general and separately for different school grades) for each DKH scores.

\section{CONCLUSIONS}

Beauty \& Health and Dietary Knowledge \& Habits are two novel research tools, designed in a fun form, using pictures, intended to assess children in the first years of obligatory education. The awareness of the role of healthy eating and its relation to the appearance of the body shape is being formed already in childhood. This is why it is worth including the early years of individuals' ontogenesis in analyses of the health of a society. Importantly, in this period schemes of perceptions of both health and the physical attractiveness of children and adults are being formed.

Both scales were designed and used as part of the "Development of beauty \& health concepts and stereotypes in middle childhood - trans-generation transmission of physical attractiveness patterns in the context of gender stereotypes and pro-health behavior" project (financed by the National Science Center in Poland). Through the use of this scale it was possible to create a model of dependencies between parents' attitudes towards one's own body and the transfer of ways of assessing appearance 
Table 9

Norms for DKH scores

\begin{tabular}{|c|c|c|c|c|c|c|c|c|c|}
\hline \multirow[t]{2}{*}{ Score } & \multicolumn{3}{|c|}{ Total } & \multicolumn{3}{|c|}{ Zero and first grade } & \multicolumn{3}{|c|}{ Second and third grade } \\
\hline & Low & Average & High & Low & Average & High & Low & Average & High \\
\hline \multicolumn{10}{|l|}{ DIETARY KNOWLEDGE } \\
\hline $\begin{array}{l}\text { Knowledge about } \\
\text { healthy products }\end{array}$ & $\leq 13$ & $14-24$ & $>24$ & $\leq 12$ & $13-21$ & $>21$ & $\leq 14$ & $15-23$ & $>23$ \\
\hline $\begin{array}{l}\text { Knowledge about } \\
\text { unhealthy products }\end{array}$ & - & $<12$ & $\geq 12$ & - & $<9$ & $\geq 9$ & $\leq 5$ & $6-14$ & $>14$ \\
\hline Correct knowledge & $\leq 26$ & $27-38$ & $>38$ & $\leq 24$ & $25-37$ & $>37$ & $\leq 29$ & $30-38$ & $>38$ \\
\hline Incorrect knowledge & $\leq 4$ & $5-12$ & $>12$ & $\leq 6$ & $7-14$ & $>14$ & $\leq 2$ & $3-7$ & $>7$ \\
\hline Lack of knowledge & $\leq 3$ & $4-14$ & $>14$ & $\leq 2$ & 3-14 & $>14$ & $\leq 5$ & $6-15$ & $>15$ \\
\hline $\begin{array}{l}\text { Knowledge about nutri- } \\
\text { tion - general score }\end{array}$ & $\leq 15$ & $16-32$ & $>32$ & $\leq 10$ & $11-29$ & $>30$ & $\leq 23$ & $24-34$ & $>34$ \\
\hline \multicolumn{10}{|l|}{ DIETARY HABITS } \\
\hline Healthy eating habits & $\leq 21$ & $22-27$ & $>27$ & $\leq 21$ & $22-27$ & $>27$ & $\leq 21$ & $22-27$ & $>27$ \\
\hline $\begin{array}{l}\text { Unhealthy eating } \\
\text { habits }\end{array}$ & $\leq 10$ & $11-17$ & $>17$ & $\leq 10$ & $11-17$ & $>17$ & $\leq 10$ & $11-17$ & $>17$ \\
\hline $\begin{array}{l}\text { Proper eating habits - } \\
\text { general score }\end{array}$ & $\leq 6$ & 6-14 & $>14$ & $\leq 6$ & 6-14 & $>14$ & $\leq 6$ & 6-14 & $>14$ \\
\hline
\end{tabular}

to 5-year-old children, as well as the formation of attitudes regarding physical attractiveness and its value in social life in the children. Results of the two-year study will explain in what ways the attitudes of 5/6 year olds translate into the levels of adequacy of the emerging image of their own body two years later.

The Beauty \& Health scale has been used to investigate the relationship between gender stereotypes and body image. As one of the components of gender stereotypes concerns female beauty, we want to verify the hypothesis that the standards of beauty and intensity of stereotypical body perception held by five-year-olds are determined by parental attitudes towards gender relations and gender stereotypization. Initial analyses revealed that 5/6-year-old girls and boys equally associate social success with a normal body shape and almost never with an obese one. Ambivalent sexism was higher among fathers than mothers, regardless of the child's sex. Mothers' ASI score was strongly related to daughters associating happiness with normal female body shape, being clever with being obese in females, and having the highest number of friends was considered to be a feature of men with normal body shape. Also the more benevolent the mother, the more often girls associated being rich with obese men. Additionally, the obese women were considered to be most clever by girls whose fathers had the highest hostile sexism results. In the case of sons, they saw obese women and men as professionally fulfilled when their father's sexism was the lowest. Also, obese men were seen as the nicest when mother's hostile sexism and father's benevolent sexism were lowest. Our results show a strong relationship between parents' sexism and children's stereotypes about body size (Lipowska, Lipowski, \& Kosakowska-Berezecka, 2016). The procedure was child-friendly - children not only performed the instructions but also added numerous spontaneous comments.

The Dietary Knowledge \& Habits scale served to investigate the relationship between the parents' styles of feeding their children and the eating habits and dietary knowledge of boys and girls (Lipowska, Lipowski, Jurek, Jankowska, \& Pawlicka, 2018). By using the scale it was possible to confirm that feeding styles preferred by the parents predict the dietary habits of their children, and as a consequence they contribute to their body fat levels. Research conducted using the Dietary Knowledge \& Habits scale also served to diagnose the knowledge about dietary products in education programs in schools and preschools in the Pomeranian Voivodeship.

The Beauty \& Health and Dietary Knowledge $\&$ Habits can be used in both research and practice. Both scales are characterized by good psychometric properties and can be used to assess 5-9 year old children for research and also be helpful in the process of assessment of the effectiveness of pro-health programs in schools and preschools. 


\section{ACKNOWLEDGMENTS}

The scales Beauty \& Health [Piękno i Zdrowie] and Dietary Knowledge \& Habits [Wiedza i Nawyki Żywieniowe] were designed and published thanks to funding from grant no. 2015/17/B/HS6/04144 from the National Science Center, Poland.

\section{ENDNOTES}

1 Polish- and English-language versions of Beauty \& Health [Piękno i Zdrowie] and supplementary materials are downloadable at https://www.pracowniatestow.pl/pl/p/Piekno-i-zdrowie/223

2 Polish- and English-language versions of Dietary Knowledge \& Habits [Wiedza i Nawyki Żywieniowe] and supplementary materials are downloadable at https://www.pracowniatestow.pl/pl/p/ Wiedza-i-nawyki-zywieniowe/224

\section{REFERENCES}

Anzman, S. L., Rollins, B. Y., \& Birch, L. L. (2010). Parental influence on children's early eating environments and obesity risk: implications for prevention. International Journal of Obesity, 34, 1116-1124. https://doi.org/10.1038/ijo.2010.43

Asbury, M. B., \& Woszidlo, A. (2016). Understanding the relationship between family communication and the development of weight stigma. Health Psychology Report, 4, 213-223. https://doi. org/10.5114/hpr.2016.57682

Bartolucci, F., Bacci, S., \& Gnaldi, M. (2016). Statistical Analysis of Questionnaires. A Unified Approach Based on R and Stata. Boca Raton, FL: CRC Press, Taylor \& Francis Group.

Branca, F., \& Nikogosian, H. T. L. (2007). Challenge of obesity in the WHO European Region and the strategies for response: summary. Denmark: World Health Organization.

Cash, T. F., \& Smolak, L. (2011). Understanding body images: Historical and contemporary perspectives. In T. F. Cash \& L. Smolak (Eds.), Body image: A handbook of science, practice, and prevention. (pp. 3-11). New York, NY, US: Guilford Press.

Coyne, S. M., Linder, J. R., Rasmussen, E. E., Nelson, D. A., \& Birkbeck, V. (2016). Pretty as a Princess: Longitudinal Effects of Engagement with Disney Princesses on Gender Stereotypes, Body Esteem, and Prosocial Behavior in Children. Child Development, 87, 1909-1925. https://doi.org/10.1111/cdev.12569

Davison, K. K., \& Birch, L. L. (2004). Predictors of fat stereotypes among 9-year-old girls and their parents. Obesity Research, 12, 86-94. https://doi.org/10.1038/oby.2004.12 de Lauzon-Guillain, B., Oliveira, A., Charles, M. A., Grammatikaki, E., Jones, L., Rigal, N., Lopes, C.,
Manios, Y., Moreira, P., Emmett, P., \& MonneryPatris, S. (2012). A review of methods to assess parental feeding practices and preschool children's eating behavior: the need for further development of tools. Journal of the Academy of Nutrition and Dietetics, 112, 1578-1602. https://doi.org/10.1016/j.jand.2012.06.356

Dohnt, H. K., \& Tiggemann, M.(2005). Peer influences on body dissatisfaction and dieting awareness in young girls. British Journal of Developmental Psychology, 23, 103-116. https://doi.org/10.1348/026151004X20658

Eagly, A. H., Ashmore, R. D., Makhijani, M. G., \& Longo, L. C. (1991). What is beautiful is good, but...: A meta-analytic review of research on the physical attractiveness stereotype. Psychological Bulletin, 110, 109-128. https://doi.org/10.1037/0033-2909.110.1.109

Griffin, A. M., \& Langlois, J. H. (2006). Stereotype Directionality and Attractiveness Stereotyping: Is Beauty Good or is Ugly Bad? Social Cognition, 24, 187-206. https://doi.org/10.1521/soco.2006.24.2.187

Harriger, J. A., Calogero, R. M., Witherington, D. C., \& Smith, J. E. (2010). Body Size Stereotyping and Internalization of the Thin Ideal in Preschool Girls. Sex Roles, 63, 609-620. https://doi.org/10.1007/s11199-010-9868-1

Kułaga, Z., Grajda, A., Gurzkowska, B., Wojtyło, M. A., Góźdź, M., \& Litwin, M. S. (2016a). The prevalence of overweight and obesity among Polish schoolaged children and adolescents. Przegląd Epidemiologiczny, 70, 641-651.

Kułaga, Z., Gurzkowska, B., Grajda, A., Wojtyło, M., Góźdź, M., \& Litwin, M. (2016b). The prevalence of overweight and obesity among Polish pre-schoolaged children. Developmental Period Medicine, 20, 143-149.

Kułaga, Z., Litwin, M., Tkaczyk, M., Palczewska, I., Zajączkowska, M., Zwolińska, D., Krynicki, T., Wasilewska, A., Moczulska, A., Morawiec-Knysak, A., Barwicka, K., Grajda, A., Gurzkowska, B., Napieralska, E., \& Pan, H. (2011). Polish 2010 growth references for school-aged children and adolescents. European Journal of Pediatrics, 170, 599-609. https://doi.org/10.1007/s00431-010-1329-x

Lemay, E. P., Jr., Clark, M. S., \& Greenberg, A. (2010). What is beautiful is good because what is beautiful is desired: physical attractiveness stereotyping as projection of interpersonal goals. Personality \& Social Psychology Bulletin, 36, 339-353. https:// doi.org/10.1177/0146167209359700

Lipowska, M., Bidzan, M., Mazurkiewicz, N., \& Lipowski, M. (2015). Jakość życia w przewlekłej widocznej chorobie a poczucie stygmatyzacji u młodych kobiet [Quality of life chronic visible illness and the sense of stigmatization in young women]. Przeglad Psychologiczny, 58, 303-323.

Lipowska, M., \& Lipowski, M. (2015). Narcissism as a moderator of satisfaction with body image in young women with extreme underweight and obesity. PLoS One, 10, e0126724-e0126724. https://doi. org/10.1371/journal.pone.0126724
Validity of Beauty \& Health and Dietary Knowledge \& Habits scales 
Lipowska, M., Lipowski, M., Jurek, P., Jankowska, A. M. \& Pawlicka, P. (2018). Gender and body-fat status as predictors of parental feeding styles and children's nutritional knowledge, eating habits and behaviours. International Journal of Environmental Research and Public Health, 15, 852. https://doi. org/10.3390/ijerph15050852

Lipowska, M., Lipowski, M., \& Kosakowska-Berezecka, N. (2016). Children's perception of social value of beauty - the role of parental gender stereotypization. Paper presented at the Appearance Matters 7, London.

Małgorzata

Lipowska, Mariusz Lipowski
Lipowski, M., \& Lipowska, M. (2015). Poziom narcyzmu jako moderator relacji pomiędzy obiektywnymi wymiarami ciała a stosunkiem do własnej cielesności młodych mężczyzn [The role of narcissism in the relationship between objective body measurements and body self-esteem of young men]. Polskie Forum Psychologiczne, 20, 31-46. https://doi.org/10.14656/PFP20150103

Llewellyn, C. H., van Jaarsveld, C. H. M., Boniface, D., Carnell, S., \& Wardle, J. (2008). Eating rate is a heritable phenotype related to weight in children. The American Journal of Clinical Nutrition, 88, 15601566. https://doi.org/10.3945/ajcn.2008.26175

Loprinzi, P. D., \& Trost, S. G. (2010). Parental influences on physical activity behavior in preschool children. Preventive Medicine, 50, 129-133. https:// doi.org/10.1016/j.ypmed.2009.11.010

Lowes, J., \& Tiggemann, M. (2003). Body dissatisfaction, dieting awareness and the impact of parental influence in young children. British Journal of Health Psychology, 8, 135-147. https://doi. org/10.1348/135910703321649123

Meule, A. (2017). Interactive effects between flexible and rigid control of eating behavior on body weight: a moderated serial multiple mediation model. Health Psychology Report, 5, 314-322. https://doi.org/10.5114/hpr.2017.70206

Nicklaus, S., Boggio, V., Chabanet, C., \& Issanchou, S. (2005). A prospective study of food variety seeking in childhood, adolescence and early adult life. Appetite, 44, 289-297.

Nishtar, S., Gluckman, P., \& Armstrong, T. (2016). Ending childhood obesity: a time for action. The Lancet, 387, 825-827. https://doi.org/10.1016/ S0140-6736(16)00140-9

Obara-Gołębiowska, M., Brycz, H., Lipowska, M., \& Lipowski, M. (2018). The Role of Motivation to Reduce Obesity among Elderly People: Response to Priming Temptation in Obese Individuals. International Journal of Environmental Research and Public Health, 15, 244.

Puhl, R. M., \& Latner, J. D. (2007). Stigma, obesity, and the health of the nation's children. Psychological Bulletin, 133, 557-580. https://doi.org/10.1037/00332909.133.4.557

Radoszewska, J. (2009). Otyły nastolatek w oczach rówieśników [Obese teenagers in the eyes of their peers]. Pediatric Endocrinology, Diabetes and Metabolism, 15, 167-171.

Ramsey, J. L., \& Langlois, J. H. (2002). Effects of the 'beauty is good' stereotype on children's information processing. Journal of Experimental Child Psychology, 81, 320-340. https://doi.org/10.1006/jecp.2002.2656

Ridgeway, R. T., \& Tylka, T. L. (2005). College Men's Perceptions of Ideal Body Composition and Shape. Psychology of Men \& Masculinity, 6, 209-220. https://doi.org/10.1037/1524-9220.6.3.209

Scaglioni, S., Arrizza, C., Vecchi, F., \& Tedeschi, S. (2011). Determinants of children's eating behavior. The American Journal of Clinical Nutrition, 94, 2006S2011S. https://doi.org/10.3945/ajcn.110.001685

Skinner, J. D., Carruth, B. R., Bounds, W., Ziegler, P., \& Reidy, K. (2002). Do food-related experiences in the first 2 years of life predict dietary variety in school-aged children? Journal of Nutrition Education and Behavior, 34, 310-315.

Slater, A., \& Tiggemann, M. (2016). Little girls in a grown up world: Exposure to sexualized media, internalization of sexualization messages, and body image in 6-9 year-old girls. Body Image, 18, 19-22. https://doi.org/10.1016/j.bodyim.2016.04.004

Strauss, R. S., \& Pollack, H. A. (2003). Social marginalization of overweight children. Archives of Pediatrics \& Adolescent Medicine, 157, 746-752. https:// doi.org/10.1001/archpedi.157.8.746

Swami, V., Frederick, D. A., Aavik, T., Alcalay, L., Allik, J., Anderson, D., ... Zivcic-Becirevic, I. (2010). The attractive female body weight and female body dissatisfaction in 26 countries across 10 world regions: results of the international body project I. Personality \& Social Psychology Bulletin, 36, 309-325. https:// doi.org/10.1177/0146167209359702

Tiggemann, M. (2004). Body image across the adult life span: stability and change. Body Image, 1, 29-41.

Tiggemann, M., \& Wilson-Barrett, E. (1998). Children's figure ratings: relationship to self-esteem and negative stereotyping. International Journal of Eating Disorders, 23, 83-88.

Tod, D., \& Edwards, C. (2013). Predicting drive for muscularity behavioural engagement from body image attitudes and emotions. Body Image, 10, 135138. https://doi.org/10.1016/j.bodyim.2012.08.010

Utter, J., Scragg, R., Schaaf, D., \& Mhurchu, C. N. (2008). Relationships between frequency of family meals, BMI and nutritional aspects of the home food environment among New Zealand adolescents. The International Journal of Behavioral Nutrition and Physical Activity, 5, 50-50. https://doi.org/10.1186/1479-5868-5-50

Wojtyniak, B., \& Goryński, P. (2016). Sytuacja zdrowotna ludności Polski i jej uwarunkowania [Health status of the Polish population and its determinants]. Warszawa: Narodowy Instytut Zdrowia Publicznego - Państwowy Zakład Higieny.

World Health Organization (2013). World Health Statistics 2013. Geneva: WHO. 